\title{
ASSESSMENT OF GRAIN QUALITIES OF WHEAT (Triticum aestivum cv. HD 2329) DURING STORAGE AGAINST KHAPRA BEETLE
}

\section{(Trogoderma granarium Everts)}

\author{
Prachi Lambat ${ }^{1}$, Ashish Lambat ${ }^{2}$, Sanjeev Charjan ${ }^{3}$ and Rajesh Gadewar ${ }^{2}$ \\ 1 Shri Mathuradas Mohota Science College, Nagpur, Maharashtra, India. \\ 2 Sevadal Mahila Mahavidyalaya, Sakkardara, Nagpur, Maharashtra, India. \\ 3 Dr. PDKV, Akola's, College of Agriculture, Nagpur,India \\ Corresponding author Email : lambatashish@gmail.com
}

\begin{abstract}
:
Khapra beetle(Trogoderma granarium Everts) is a serious pest of stored grain causing considerable damage to almost all cereals in storage. It is largely responsible for damage and frequently harboring stores, mill and warehouses. Khapra beetle is composition in nature attributing about $50 \%$ loss in seed weight during storage.
\end{abstract}

\section{Keywords}

organic grain protectants, seed flag, custard apple, khapra beetle, wheat, infestation, storage.

\section{Introduction:}

Khapra beetle (Trogoderma granarium Everts) is a serious pest of stored grain causing considerable damage to almost all cereals in storage. It is largely responsible for damage and frequently harboring stores, mill and warehouses. Khapra beetle is cosmopolitan in nature attributing about 50\% loss in seed weight during storage. The steady rise in the use of pesticides for control of store grain pests can be dangerous to human being and cattle as well due to their residual toxicity. With view to find out safe and organic seed protectants, present investigation was taken up to evaluate the organic grain protectantsi $n$ seed storage against khapra beetle in wheat.

\section{Material and Method:}

Wheat (Triticum astivum cv. HD2329 )seed were used in various phages of this study, produced in 2008-2009. The seed were cleaned and dried(moisture content $10.5 \%$ ). The wheat seed were treated (may 2009)with six plant product 
viz. Neem leaf, sweet flag, Tulsi, custard apple, Turmeric and pongamia powder is in the proportion of $2.5 \%$ by weight of the seeds. The experiment as conducted in glass bottle of 1 lit capacity with seven treatments including untreated control. Each glass bottle was then filled with $500 \mathrm{gm}$ of wheat seeds. 10 pairs of 2-3 days old khapra beetle were released in each glass bottle covered with muslin cloth, the set of experiment was kept in well ventilated wire mesh almirah in masonry building having cemented walls, roof and floor under ambient temperature (24.1-45.80c) and relative humidity (20-85\%) from May to Jully, 2009. After three months the seed from each treatment were keenly observed and those found infested were separated out weighted to determine the infestation percentage on weight basis, hundred seed weight and germination were tested in quadruplicate with 100 seed in each replication. He germination percentage was evaluated on the value of normal seedling (Anon.1985). the vigour index were workout following the method of Abdul Baki and Anderson (1973). For field emergence test, sowing of wheat seed was done in randomized block design, with four replication with inter and intra row spacing of one feet and six inches respectively. Observation for field emergence were recorded daily and finally the established seedling were counted after one month of sowing . the experimental data was statistically scrutinized as per the panse and sukhatme (1967).

\section{Result and Discussion:}

The data regarding the effect of the different organic grain protectants on population behaviour (Adult mortality), infestation percentage, 100 seed weight, germination percentage, vigour index and field emergence percentage after three month of storage are given in Table 1 The result indicated that variation in number of khapra beetle (adult)in each treatment. The khapra beetle adult mortality was significantly highest in wheat seed treated with sweet flag $(100 \%)$ which is closely followed by custard apple $(92 \%)$, neem leaf $(60 \%)$, Pongamia (56\%), tulsi $(51 \%)$ and turmeric $(47 \%)$. Where in significantly 
lower mortality was observed in untreated control (5\%). Saxena et al. (1976). Tikku et al. (1978) and Khan and Borle (1985) found Acorus calamus L oil vapour responsible for causing infecundity among the female of a number stored grain pest. Birdar (2000) who reported that sweet flag has got insecticidal and ovicidal effect. The significantly wheat seed weight loss was observed in untreated control followed by turmeric, tulsi, pongamia, neem leaf, custard apple and sweet flag treatment during entire period of storage. This might due to sterilizing effect of sweet flag rhizome powder mixed withwheat seeds Charjan and Tarar (1994). Deshpande et al. (2010), Ashish et al. (2011)and K. Charjan et al. (2011) reported that the sharp declined in infestation percentage of store grain pest in seed treated with Acorus calamus powder during storage. The seed quality parameters viz., 100 seed weight, germination percentage and seedling vigour index was highest in seed treated with $2.5 \%$ concentration of sweet flag powder followed by custard apple, neem leaf, pongamia, tulsi,turmeric and untreated control. The 100 seed weight, germination percentage and vigour index decreased with increasing infestation of stored grain pest. Howe (1972), Charjan and Tarar (1994), Deshpande et al. (2010) and Ashish Lambat et al. (2011). Since the stored grain pest have been eaten off major portion of the endosperm which leads to reduction in weight of the wheat seeds and in turn affect the seed germination and vigour index because of lack of stored food and is conformity with the findings of Narayanswami (1985). Handerson and Christensen (1961) reported the pulse beetle attack the embryo and germination potential of seed reduced or totally destroyed. The field emergence percentage of wheat seeds follow the same trend of seed quality parameters. The field emergence percentage was highest in seed treated with $2.5 \%$ concentration of sweet flag powder as compared to other treatments and untreated control. This might be due to the least infestation of khapre beetle and higher 100 seed weight, germinability and seedling vigour index. The results are agreement to vigour those reported by Charjan and Tarar (1994), Deshpande et al.(2010), Ashsh Lambat et al. (2011) and K. Charjan et 
al. (2011). Among the plant products sweet flag powder $2.5 \%$ were found o be significantly effective against khapra beetle through out the period of investigation.

\section{Conclusion:}

These findings are agreement with Siva Srinivasu (2001), Deshpande et al. (2010), Charjan and Tarar (1994) and Ashish Lambat et al. (2011). Thus sweet flag and custard apple naturally occurring botanicals which are not toxic can be used as pre storage seed treatment, dispensing with the use of costly and toxic chemicals to control khapra beetle damage without adversely affecting the germination of wheat seed.

\section{Reference:}

Abdul Baki A.A.and Anderson J.D. 1973 Vigour determination in soybean seed by multiple criteria. Crop sci. 13: 630-633.

Anonymous, 1985 Internationalrules for seed testing. Seed sci and Technol. 13: 299- 513.

Ashish Lambat, Rajesh Gadewar, Sanjeev Charjan, Konglath Cherian and Prachi Lambat, 2011. Evaluation of organic grain protectants in seed storage against rice weevil in wheat. Proc. of international conference on sustainable environment held during 19-20 february 2011 at Aurangabad. Maharasstra India . Special issue 6: 122-123.

Biradar B. S. 200 Prevention of cross infestation by Sitophilus oryzae L. and Rhizopertha dominica in stored wheat. M. Sc. (Agri.) Thesis, University of Agricultural sciences, Dharwad. Charjan S.K.U. and Tarar, J. L. 1994 The influence of some plant products on seed quality of Lobia during storage . Ann. Plant Physiol. 8(2)L: 153-156.

Deshpande, V. K. and Christenson, C. M. 1961 Preharvest control of insect and fungi. U. S. Dept. Agri. Ybk, pp.348-356. 
Howe, R. W. 1972 Insect attacking seed during storage. Seed Biology vol. III (ed. Kozlowski, T. T.) Academic press: New York pp. 247-300.

Khan M. I. and Borle, M. N. 1985Efficacy of some safer grain protectants agaist the pulse beetle, Collosobruchus chenensis 1. Infecting stored Bengal gram (Cicer arietinum L.). P. K. V. Res. J. 9(1): 53-55.

Konglath Cherian, Sanjeev Charjan, Vandan Mohod, Ashish Lambat and Rajesh Gadewar 2011. Studies on the influence of Acorus calamus L. rhizome powder seed treatment against stored grain pest of wheat. Proc. Of National Seminar on Environmental Management and Biodiversity Conservation, held during 26-27 February 2011 at Rishikesh (U. K.) India. Abstract no.A127 page 101. Narayanaswasmy, S 1985 Effect of pulse beetle damage on seed quality of field bean and pigeon pea. Seed Res. 13(2): 138-141.

Panse, V. G. and Skhatme, P. V. 1967. Statistical methods for agricultural workers. I. C. A. R. Pub., New Delhi. Saxena, B.P., Koul, O. and Tikku, K.1976. Non toxic protectants against the stored grain insect pest. Bull. Grain Technol. 14(5): 190-193.

Tikku K., Koul, O. and Saxena B. P. 1978. The influence of Acorus Calamus L. oil vapour on the histocytological pattern of the ovaries of Trogoderma granarium Evert. Bull. Grain Technol. 16 (1): 3-9. 
Table no. 1: The effect of different organic protectants on khapra beetle mortality, infestation percentage, 100 seed weight, germination percentage, seedling vigour and field emergence percentage.

\begin{tabular}{|l|c|c|c|c|c|c|}
\hline Treatments & $\begin{array}{c}\text { Adult } \\
\text { mortality } \\
(\%)\end{array}$ & $\begin{array}{c}\text { Percent } \\
\text { weight loss } \\
\text { due to } \\
\text { infestation(\%) }\end{array}$ & $\begin{array}{c}\mathbf{1 0 0} \\
\text { seed } \\
\text { weight } \\
\text { (g) }\end{array}$ & $\begin{array}{c}\text { Germination } \\
\text { (\%) }\end{array}$ & $\begin{array}{c}\text { Seedling } \\
\text { vigour } \\
\text { index } \\
\text { (SVI) }\end{array}$ & $\begin{array}{c}\text { Field } \\
\text { emergence } \\
\text { (\%) }\end{array}$ \\
\hline $\begin{array}{l}\text { Neem leaf } \\
(2.5 \%)\end{array}$ & 60 & 5.8 & 3.02 & 69 & 1338 & 57 \\
\hline $\begin{array}{l}\text { Sweet flag } \\
(2.5 \%)\end{array}$ & 100 & 0.05 & 3.32 & 96 & 2018 & 88 \\
\hline Tulsi (2.5\%) & 51 & 6.4 & 2.91 & 65 & 1291 & 55 \\
\hline $\begin{array}{l}\text { Custard } \\
\text { apple(2.5\%) }\end{array}$ & 92 & 2.4 & 3.17 & 93 & 2006 & 94 \\
\hline Turmeric(2.5\%) & 47 & 6.8 & 2.85 & 61 & 1124 & 50 \\
\hline Pongamia(2.5\%) & 56 & 6.0 & 2.97 & 64 & 1202 & 53 \\
\hline $\begin{array}{l}\text { Untreated } \\
\text { control }\end{array}$ & 5 & 17.14 & 2.01 & 35 & 682 & 22 \\
\hline SEm \pm ( $)$ & 0.35 & 0.09 & 0.03 & 0.12 & & 0.10 \\
\hline CD at 5\% & 1.06 & 0.29 & 0.10 & 0.36 & & 0.31 \\
\hline
\end{tabular}

The effect of different organic protectants on Khapra beetle mortality, infestation percentage, 100 seed weight, germination percentage and field emergence percentage.

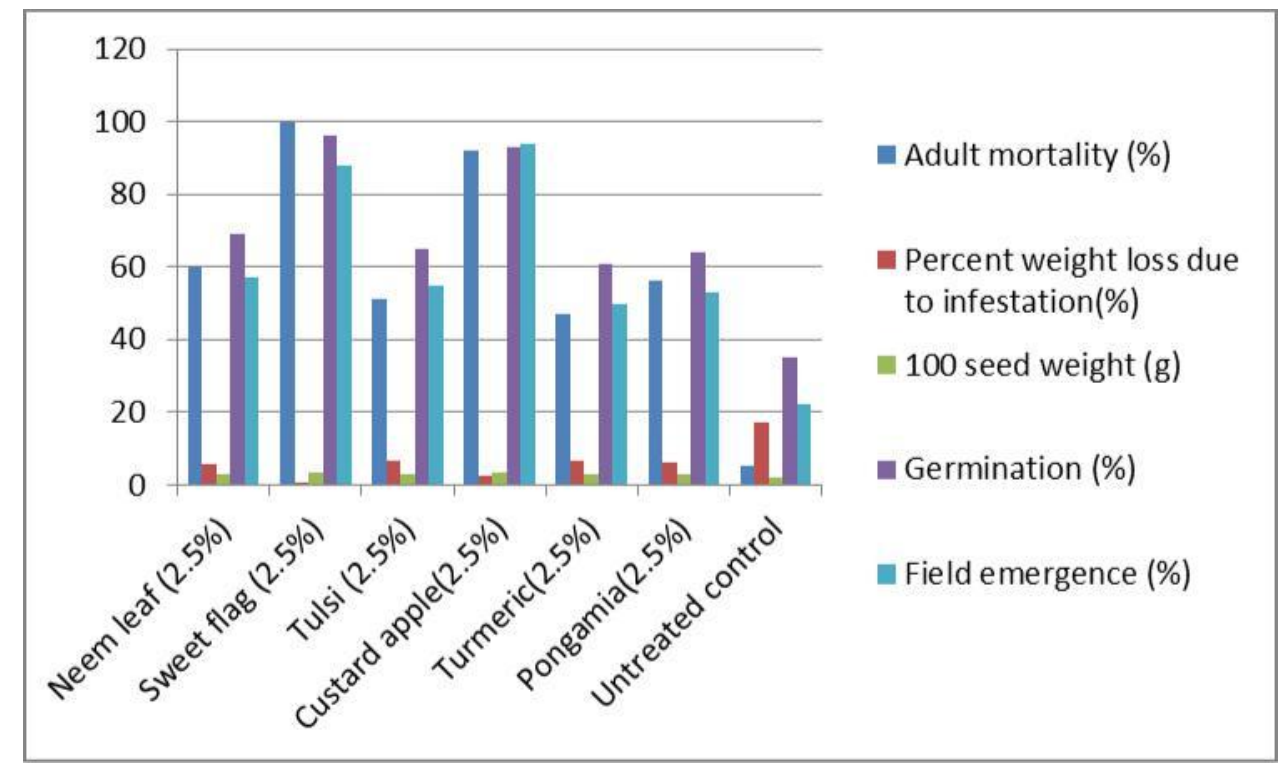

A Four Monthly Peer Reviewed Journal VISHWASHANTI MULTIPURPOSE SOCIETY (GLOBAL PEACE MULTIPURPOSE SOCIETY) 